International Journal of Instruction e-ISSN: 1308-1470 • www.e-iji.net

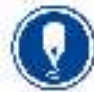

Article submission code: 20200531170416
Received: 31/05/2020

Revision: 11/01/2021
July $2021 \bullet$ Vol.14, No.3

p-ISSN: 1694-609X

pp. 645-660

Accepted: 05/02/2021

OnlineFirst: 10/06/2021

\title{
An Influence of the Contextual-Based Discovery Learning Model on the Academic Honesty of High School Students
}

\author{
Sugiarti \\ Universitas Negeri Makassar, Indonesia, atisugiarti34@yahoo.co.id \\ Halimah Husain \\ Universitas Negeri Makassar, Indonesia,ima_husain@yahoo.com.sg
}

\begin{abstract}
Academic honesty is a fundamental property of character values from an early age. It should be integrated into every learning process in the context of habituation towards continual learning. This study aimed to investigate student's academic honesty through acid-base material in chemistry using contextual-based discovery learning (CDL) model. By employing quasi-experimental design, it involves 238 participants at four high schools, which were divided into experimental group and control group. Academic honesty assessment is carried out during learning and tests. Observation and interviews used to collect data on student's academic honesty. The results reveal that implementing CDL in acid-base material of chemistry subject affects student's academic honesty. The result of academic honesty test and observation showed that the academic honesty of students that though by CDL was higher than learning without CDL. A specific material of acidbase in chemistry becomes media that confronts students directly with real situations combined with proper prior knowledge that can lead to the character value of honesty as integrated with Indonesian Character-based Curriculum.
\end{abstract}

Keywords: academic honesty, acid-base, discovery learning, approach, learning

\section{INTRODUCTION}

Honesty is at the heart of our understanding of a positive attitude that must be embedded in students at an early age. In some universities, revealing academic dishonesty is widely recognized as a worsening trend, associated with the expansion of the internet (Brew \& Sachs, 2007). One of the places to train and develop honesty is at school because that is where students are guided and educated in all ways continuously, in the long run, to produce a nation's next-generation with dignity and can apply it in everyday life. Academic honesty is following the implementation of the Character-based Curriculum or Curriculum 2013 (K-13), which promotes character education. The character curriculum being implemented in Indonesian Secondary School is supported by the discovery learning approach, project-based learning, and problem-based learning to support student learning in the classroom (Halimah \& Paramma, 2019). Khotimah,

Citation: Sugiarti., \& Husain, H. (2021). An influence of the contextual-based discovery learning model on the academic honesty of high school students. International Journal of Instruction, 14(3), 645-660. https://doi.org/10.29333/iji.2021.14338a 
Fadhli, \& Habibi (2017) describes that within students, there is a strict rule system through the integration of the honesty value in the classroom learning process. Further, Koesoema (2010) showed that four considerations could be implemented at schools to build student's academic honesty, for instance (1) educating ethical values; (2) exemplary behavior; (3) establishing key priorities, and (4) praxis and priority as proofs of academic honesty implementation. Besides, these values can be implemented in the following five aspects of academic honesty:

\section{Students are taught to do their tasks}

Completing tasks individually for each student seems to have not been regulated well. Most of them only play around and tend to receive materials passively in the classroom. Under the circumstances, the teacher should find a solution immediately to engage them and arouse curiosity to be involved in the learning. An instance of this is that a teacher can adjust students' characteristics with a given subject. We can create a familiar and passionate learning atmosphere, for one thing, cooperative learning as in contextualbased discovery learning (CDL) model. Students are accustomed to doing their tasks initially as they want to, which later can lead them to complete tasks genuinely without any force and the ability to regulate themselves following their rights and obligations. It is purposed to make them able to deal with their problems (Kustyarini, 2020). By doing tasks independently, it produces initiative, efforts to pursue achievement, selfconfidence as well as practices academic honesty that will improve their comprehension towards lessons so that learning outcomes can be achieved maximally along with honesty embedment.

\section{Avoiding asking for others' answers during an exam}

Regarding other behaviors shown by students related to academic honesty, one of them is by not asking for answers during an exam. This behavior is to train their selfconfidence and responsibility to deal with learning outcomes that they have achieved. In other words, students will be able to identify to what extent their ability to grasp taught materials. Eventually, they become more confident and independent in all aspects.

\section{Avoiding copying others' answers during an exam}

Cheating during an exam is a worrying phenomenon because it will damage the doers. Academically it harms students because the teacher cannot measure their academic abilities accurately, even their standard competency (Davis \& Drinan, 2009). The phenomenon also illustrates that students have low confidence in what they know and understand. Nevertheless, a solution to cope with this is focusing on the external controls such as examination supervision, regulations, and penalties.

\section{Avoiding looking at crib notes during an exam}

One avoiding behavior from cheating is by not looking at crib notes during an exam. Staying away from such a thing reveals students' actual academic ability. In that way, they will develop their potential positively through maximum, independent, and resilient efforts. 


\section{Students draw their conclusion}

In the case of applying discovery learning, the teacher acts as a guide by providing opportunities for students to learn actively. Through it, the teacher allows students to become a problem solver, or as a scientist, so they will be able to carry out activities such as finding information, integrating, and making their conclusions. It can be a measure of how deep a student's understanding of learning materials (C. Sugano \& Nabua, 2020).

Regarding the issue of academic honesty, several steps have been elaborated to avoid cheating and other dishonest behaviors. In the digital era, there were many ways and facilities to track scientific papers to avoid plagiarism and strict supervision during the exam. The provided facilities were conclusively proven in applying penalties as a deterrent effect (Ledwith \& Rísquez, 2008).

In terms of the learning process, one of the learning models that is expected to be able to bring up the student's academic honesty is discovery. It directs students to be actively involved in using mental processes to find concepts according to their abilities through media around the environment. Their involvement in meaningful learning is because this model has six learning stages related to building thought structures. Therefore, they will discover a concept not in the form of knowledge-transferring of teacher, but from an independent discovery. learning connects the subject's matter, especially in acid-base material, with the students' real-life so that they can integrate the knowledge they possess as an application in daily life (Salfrika, 2016). As in common, acid-base material is closely related to the students' daily lives, whether in terms of food, clothing, and shelter. The discovery of concepts independently supported by facts in the environment is expected to be able to influence the student's academic honesty.

To sum up, it is essential to embed it into students as the nation's next generation. Instilling academic honesty is very important because it is a provision for students to live their daily lives and to be successful in life. The background as mentioned earlier underlies the researchers to conduct a study on academic honesty amongst the students through CDL model at high schools of South Sulawesi. The results of this study are expected to provide information to readers about the need to apply a learning model that is able to practice student academic honesty such as the CDL model.

\section{Literature Review}

A recent study on academic honesty was conducted by Naghdipour \& Emeagwali (2013) showed that students did not report severe forms of cheating, but indicate a tendency to be involved in academic dishonesty. Sims (1993) and Bolin (2004) investigated the extent and severity of academic dishonesty that occurred in undergraduate studies related to the severity of dishonesty during work. Self-reported data collected from 60 MBA students show that subjects who claimed to have been involved in various academic dishonesty also acknowledged their various job-related dishonesty. Besides, these subjects whose behaviors are categorized as disdainful at the university level are also involved in dishonest behaviors in the workplace. Bolin (2004) added that the points out that academic dishonesty is an ongoing and pervasive problem on campuses. 
Several researchers have identified various factors that influence academic dishonesty. The study was an examination of the role of self-control, attitudes toward academic dishonesty, and perceived opportunities in predicting academic dishonesty. In short, attitudes towards academic dishonesty are mediated for its relationship between selfcontrol and academic dishonesty and also between perceived opportunities and academic dishonesty.

Further study on academic honesty, Khotimah et al. (2017) examines the effectiveness of Classroom Developmental Bibliotherapy (CDB), specifically in the Indonesian language course, to improve student's academic honesty. The measurement uses the academic honesty scale in three aspects: attitudes, tendencies, and behaviors to avoid cheating. The results show that $\mathrm{CDB}$ was effective in increasing student's academic honesty. The increase in academic honesty is due to the proper use of CDB in embedding honesty value to students. It is appropriate in developing student's moral reasoning, especially about honesty. Besides, Anderman \& Koenka (2017) explored the relationship between cheating in higher education and academic motivation usually approach motivation as a goal that students seek to achieve, so they measure it using the tools proposed by achievement goal orientation theory. Shmeleva \& Semenova (2019), Gizhitsky (2014), Gizhitsky, Gordeeva (2015) and Shmeleva (2016) found that academic dishonesty among college students is often associated with low academic motivation.

Similarly, Munir, Ahmad, \& Shahzadi (2011) examines student's academic dishonesty at the university level as a common problem that crosses all disciplines. The findings show that the most significant academic dishonesty among Gujrat University's students is sabotage. Several most essential factors are sabotage, electronic fraud, and outside help. The results of this study reveal that sabotage, electronic cheating, and external backup are the most important variables for predicting student's academic dishonesty at Gujrat University.

A previous study by Sugiarti \& Husain (2019) conduct research on the correlation between academic honesty and curiosity with student's learning outcomes using CDL with a population of 498 students consisting of three high schools and samples of 182 students. The results found that there is a significant and positive correlation between academic honesty and student's learning outcomes. In a detailed description, there is a significant correlation between curiosity and student's learning outcomes.

Langa (2013) and Anderman \& Koenka (2017) identified students' attitudes towards academic honesty through investigating their opinions about plagiarism in reports, licensing letters, copying, or cheating on bachelor or semester exams and coping methods. Those reveal and provide data that students have an awareness of the importance of academic honesty to attain competence as participation in a study program.

It was needed an effort to address the academic dishonesty. Morris (2018) developed five considerations undertaken to address cheating behavior within universities. The five considerations for higher education are determining academic 
integrity strategies, reviewing institutional policies, understanding students, reviewing the assessment process, and the implications of professional staff development. In this study, the researchers were identify the influence of learning model to address the academic dishonesty.

Based on rationalization on the background and literature review, it is considered necessary to conduct an experimental research to describe the influence of the CDL model on the academic honesty of high school students.

\section{METHOD}

\section{Research Design}

The study uses a quasi-experimental design to gain insights into determining the influence among variables and testing the existing hypotheses. The independent variable is CDL, whereas the dependent variable is the student's academic honesty. Here are the following terms of the research design:

\section{$01 \mathrm{X} \quad \mathrm{O2}$}

$03 \quad 04$

Where: $\mathrm{O} 1$ and $\mathrm{O} 3$ = student's academic honesty before treatment;

$\mathrm{O} 2$ = student's academic honesty after the application of CDL;

$\mathrm{O} 4$ = student's academic honesty without the application of CDL;

$\mathrm{X}=$ Contextual-Based Disecovery Learning

\section{Participants and Sampling Technique}

The population in this study consisted of eleventh-grade students in high schools who took the natural sciences department in South Sulawesi with a total population of 441 public schools. By using simple random sampling, this study involved four public high schools representing the city of Makassar and one public high school located in a district near from Makassar. These public high schools were SMAN 1 Gowa, SMAN 4 Makassar, SMAN 1 Takalar, and SMAN 9 Maros. By using simple random sampling, this study involved two groups for each school, and the experimental and control groups were determined by lot. The targeted participants were 238 students out of a total of 745 students.

\section{Instruments}

The quality of a study is mostly considered by the quality of research instruments and data collection. This study uses data collection instruments in the form of an observation sheet containing five indicators of academic honesty through the Guttman Scale to obtain a fixed answer of interval data or dichotomous ratios (yes-no) (Sugiyono, 2017). Open-ended interview applied to obtain in-depth information regarding academic honesty and responses to Chemistry lesson in the form of information about parents and family guidance or assistance at home in completing daily chores, parental advice concerning honest behavior, and information related to chemistry lesson at the schools. The instruments of research were validated by expert and empirical validation before 
use to ensure that the instruments were valid and reliable. For empirical validation by using Microsoft Excel, the result of analysis showed that the instruments were valid (0.376-0.801) and reliable (0.977).

\section{Data Analysis}

The collected data is analyzed using descriptive statistics and inferential statistics. As for the essential purpose of descriptive statistical analysis, it is to describe sample data which are presented in tabular form and calculate the highest and lowest scores, average, median, mode, mean, percentage and standard deviation.

Data analyzed with descriptive statistics are fully obtained through observations, questionnaires, and learning outcomes in the form of the highest score, lowest score, mean, and mode as well as performance data through student's worksheet. The observation results of academic honesty and student's worksheet at each meeting described by scores are then calculated into grades using the following formula:

$$
\text { Total scores }=\frac{\text { the score obtained by a student }}{\text { maximum score }} \times 100
$$

Regarding it, the scores obtained are then categorized into the predicates good, fair, poor, very poor with the percentage magnitude as in Table 1.

Table 1

Percentage category of student's academic honesty

\begin{tabular}{ll}
\hline Category & Percentage \\
\hline Very Good & $76 \%-100 \%$ \\
\hline Good & $56 \%-75 \%$ \\
\hline Fair & $40 \%-55 \%$ \\
\hline Poor & $<40 \%$ \\
\hline
\end{tabular}

An analysis of inferential statistics is aimed at testing hypotheses and generalizing sample data towards the population. It employs the observation results of observations of academic honesty in the experimental control groups. The analysis tests the hypotheses by using a t-test. Before testing it, pre-test in particular normality and homogeneity tests are conducted. However, data results of SMA Negeri 1 Takalar and SMA Negeri 9 Maros do not meet the pre-test requirements, which then processed using Mann-Whitney as a nonparametric test (Sugiyono, 2017).

The normality test is employed to test whether the data obtained comes from a population that is normally distributed or not by using Chi-Square Test. The homogeneity test is purposed to determine the observed data, whether it comes from a homogeneous population or not. It can be calculated using the following formula:

$$
\mathrm{F}_{\text {count }}=\frac{\text { High variance }}{\text { Low variance }}
$$


Homogeneity test's criteria comprise a significant level $\alpha=0.05$ and if $\mathrm{F}_{\text {count }}<\mathrm{F}_{\text {table }}$ then the data are homogeneous.

Hypothesis test was carried out in the two-party setting, specifically the average similarity test with the formulation of a hypothesis as follows:

$$
\begin{aligned}
& \text { H0: } \mu 1 \leq \mu 2 \\
& \text { H1: } \mu 1>\mu 2
\end{aligned}
$$

Descriptions:

$\mathrm{H}_{0}=$ no correlation between CDL and student's academic honesty;

$\mathrm{H}_{1}=$ there is a correlation $\mathrm{s}$ between CDL and student's academic honesty;

$\mu 1=$ the average scores of student's academic honesty in the experimental group;

$\mu 2=$ the average scores of student's academic honesty in the control group;

Hypothesis test's criteria comprise some requirements, that is if $-\mathrm{t}(1 / 2 \alpha, \mathrm{dk}) \leq \mathrm{t}_{\text {count }} \leq+$ $\mathrm{t}\left(1 / 2 \alpha\right.$,dk), with $\alpha=0,05$ and $\mathrm{dk}=\mathrm{n}_{1}+\mathrm{n}_{2}-2$ then $\mathrm{H}_{0}$ is accepted and $\mathrm{H}_{1}$ is rejected. It implies that there is no correlation between CDL and student's academic honesty. Conversely, $t_{\text {count }}>t_{\text {table }}$ and $t_{\text {count }}<-t_{\text {table }}$, then $\mathrm{H}_{0}$ is rejected, and $\mathrm{H}_{1}$ is accepted, which means there is a correlation between CDL and student's academic honesty.

Concerning research samples at SMA Negeri 1 Takalar and SMA Negeri 9 Maros which do not meet the pre-test requirements for its homogeneous and normal samples, MannWhitney $\mathrm{U}$ test is then conducted by using the formula (Yusuf, 2016) as follows:

$$
\left.\left.\mathrm{U}_{1}=\mathrm{n}_{1} \mathrm{n}_{2}+\frac{n 1(n 1+1)}{2}-\sum R 1\right) \quad \text { or } \mathrm{U}_{2}=\mathrm{n}_{1} \mathrm{n}_{2}+\frac{n 1(n 1+1)}{2}-\sum R 2\right)
$$

Where: $\mathrm{U}=$ Scores sought;

$\mathrm{N} 1=$ number of data in the experimental group;

$\mathrm{N} 2$ = number of data in the control group;

$\sum \mathrm{R} 1=$ number of experimental group sequences;

$\sum \mathrm{R} 2=$ number of control group sequences

Furthermore, it calculates $Z_{\text {count }}$ score as confirmed with $Z_{\text {table }}$ to determine the acceptance of the null hypothesis and experiment. The hypothesis test's criteria explain if, at $\alpha=0.05$, there is an occurrence of $=Z_{\text {count }}>Z_{\text {table }}$, which implies that $H_{0}$ is rejected and $\mathrm{H}_{1}$ is accepted or, in other words, there is a correlation between CDL and student's academic honesty. On the contrary, if $Z_{\text {count }}<Z_{\text {table }}$, then $H_{0}$ is accepted, and $H_{1}$ is rejected, which means that there is no correlation between CDL and student's academic honesty, especially for acid-base material.

\section{FINDINGS}

The analysis results of descriptive statistics are used to determine the highest and the lowest scores, average, median, mode, and standard deviation of student's academic honesty in the four observed schools. Here are the following descriptive statistical analysis data that has been obtained as in Table 2 . 
Table 2

Statistical data of student's academic honesty

\begin{tabular}{llllccccc}
\hline & \multicolumn{2}{c}{ SMAN 6 Takalar } & \multicolumn{2}{c}{ SMAN 1 Gowa } & \multicolumn{2}{c}{ SMAN 4 MKS } & \multicolumn{2}{c}{ SMAN 9 Maros } \\
\cline { 2 - 9 } & $\begin{array}{l}\text { Experimental Control } \\
\text { Group }\end{array}$ & $\begin{array}{l}\text { Experimental Control } \\
\text { Group }\end{array}$ & $\begin{array}{l}\text { Experimental Control } \\
\text { Group }\end{array}$ & $\begin{array}{l}\text { Experimental } \\
\text { Group }\end{array}$ & $\begin{array}{l}\text { Control } \\
\text { Group }\end{array}$ & $\begin{array}{l}\text { Group } \\
\text { Group }\end{array}$ \\
\hline $\begin{array}{l}\text { Sample Size } \\
\text { The Lowest } \\
\text { Scores }\end{array}$ & 29 & 29 & 30 & 30 & 30 & 30 & 30 & 30 \\
\hline $\begin{array}{l}\text { The Highest } \\
\text { Scores }\end{array}$ & 72 & 24 & 44 & 20 & 44 & 24 & 28 & 16 \\
\hline Average & 56.17 & 36.94 & 59 & 36 & 76 & 56 & 68 & 48 \\
\hline Median & 55.58 & 37.3 & 62.66 & 33.38 & 65.15 & 43.5 & 47.72 & 34.5 \\
\hline Mode & 65.8 & 38 & 65.16 & 32 & 65.16 & 45.34 & 45 & 37.42 \\
\hline $\begin{array}{l}\text { Standard } \\
\text { Deviation }\end{array}$ & 8.39 & 5.31 & 7.97 & 6.49 & 7.97 & 6.21 & 10.63 & 8.2 \\
\hline
\end{tabular}

Based on the data in Table 2, it shows that the control groups in all four schools for the lowest scores are categorized as very poor. It indicates that conventional learning by the teacher so far has not integrated the value of academic honesty. While in the experimental groups for the lowest scores, all groups are in the poor category. Though it can be assumed that learning with the CDL has introduced the value of academic honesty through its integration in acid-base material of chemistry subject.

The presented information on the highest scores for the control group shows that it is in the poor category, whereas the experimental group is in the fair and reasonable category. Both groups indicate that learning with the CDL instills academic honesty for students intensively through its integration with acid-base material.

Regarding the average percentage of students' learning performance as many as five meetings for each school, which are taught using CDL presented through the exercise performance of the student's worksheet, as seen in Table 3 .

Table 3

Percentage of students' worksheet performance

\begin{tabular}{llllll}
\hline \multirow{2}{*}{ Syntax } & \multicolumn{3}{l}{ List of Schools } & & \\
\cline { 2 - 5 } & $\begin{array}{l}\text { SMAN 6 } \\
\text { Takalar }\end{array}$ & $\begin{array}{l}\text { SMAN } \\
\text { 1 Gowa }\end{array}$ & $\begin{array}{l}\text { SMAN 4 } \\
\text { Makassar }\end{array}$ & $\begin{array}{l}\text { SMAN } \\
\text { 9 Maros }\end{array}$ & $\begin{array}{l}\text { Categories of } \\
\text { Performance Level }\end{array}$ \\
\hline Stimulation & 57.30 & 541.1 & 65.25 & 45.33 & Fair - Good \\
\hline Problem Identification & 60.20 & 63.23 & 73.30 & 54.20 & Fair - Good \\
\hline Data Collection & 69.18 & 65.40 & 76.05 & 68.08 & Good - Very Good \\
\hline Data Processing & 76.23 & 79.14 & 83.13 & 71.24 & Good - Very Good \\
\hline Verification & 73.14 & 75.22 & 85.23 & 65.25 & Good - Very Good \\
\hline Generalization & 79.30 & 81.23 & 87.35 & 67.14 & Good - Very Good \\
\hline
\end{tabular}

As Table 3 shows, the students' activities in examining the syntax of stimulation confronted with a problem raised curiosity. It is expected that they will have a level of understanding towards the learning objectives, which can be identified from their abilities to associate the stimulus with learning objectives' indicators. The stimulus delivered at each meeting is often juxtaposed with types of substances found around them and based on their experience. 
Here are the following several aspects of student's academic honesty assessment based on the respective indicator for each school presented in Table 4.

Table 4

Student's academic honesty

\begin{tabular}{|c|c|c|c|c|c|c|c|c|c|c|c|c|c|c|c|c|}
\hline \multirow{3}{*}{ No } & \multicolumn{4}{|c|}{ SMAN 6 Takalar } & \multicolumn{4}{|c|}{ SMAN 1 Gowa } & \multicolumn{4}{|c|}{ SMAN 4 Makassar } & \multicolumn{4}{|c|}{ SMAN 9 Maros } \\
\hline & \multicolumn{2}{|c|}{ Exp } & \multicolumn{2}{|c|}{ Control } & \multicolumn{2}{|c|}{ Exp } & \multicolumn{2}{|c|}{ Control } & \multicolumn{2}{|c|}{ Exp } & \multicolumn{2}{|c|}{ Control } & \multicolumn{2}{|c|}{ Exp } & \multicolumn{2}{|c|}{ Control } \\
\hline & $\bar{X}$ & Ctgry & $\bar{x}$ & Ctgry & $\bar{x}$ & Ctgry & $\bar{x}$ & Ctgry & $\bar{x}$ & Ctgry & $\bar{x}$ & Ctgry & $\bar{x}$ & Ctgry & & $\begin{array}{c}\text { Ctgr } \\
\mathrm{y}\end{array}$ \\
\hline 1 & 64.8 & $\mathrm{G}$ & 34.4 & $\mathrm{P}$ & 62.6 & $\mathrm{G}$ & 33.3 & $\mathrm{P}$ & 78 & VG & 44 & $\mathrm{~F}$ & 52 & $\mathrm{~F}$ & 30.4 & $\mathrm{P}$ \\
\hline 2 & 59.3 & $\mathrm{G}$ & 44.2 & $\bar{F}$ & 37.3 & $P$ & 28.7 & $P$ & 67.7 & $\mathrm{G}$ & 44 & $\mathrm{~F}$ & 45.2 & $\bar{F}$ & 35.3 & $\mathrm{P}$ \\
\hline 3 & 54.5 & $\mathrm{~F}$ & 31.7 & $\mathrm{P}$ & 34.7 & $\mathrm{P}$ & 31 & $P$ & 44.3 & $\mathrm{~F}$ & 39.3 & $\mathrm{P}$ & 53.3 & $\mathrm{~F}$ & 29.3 & $\mathrm{P}$ \\
\hline 4 & 25.7 & $\mathrm{P}$ & 31,7 & $\mathrm{P}$ & 36 & $\mathrm{P}$ & 38 & $\mathrm{P}$ & 43.3 & $\mathrm{~F}$ & 38.7 & $\mathrm{P}$ & 46 & $\mathrm{~F}$ & 35.3 & $\mathrm{P}$ \\
\hline 5 & 76.6 & $\mathrm{VG}$ & 44.9 & $\mathrm{~F}$ & 65.4 & $\mathrm{G}$ & 35.9 & $\mathrm{P}$ & 80 & $\mathrm{VG}$ & 44 & $\mathrm{~F}$ & 50.7 & $\mathrm{~F}$ & 34.7 & $\mathrm{P}$ \\
\hline $\begin{array}{l}\text { Des } \\
1= \\
2= \\
3= \\
4= \\
5=\end{array}$ & $\begin{array}{l}\text { ription } \\
\text { lo their } \\
\text { voidin } \\
\text { voidin } \\
\text { voidin }\end{array}$ & $\begin{array}{l}\text { own t } \\
\text { g askin } \\
\text { g copy } \\
\text { g looki } \\
\text { their }\end{array}$ & $\begin{array}{l}\text { sks } \\
\text { for o } \\
\text { ag oth } \\
\text { g at c }\end{array}$ & $\begin{array}{l}\text { thers' } \\
\text { ers' an } \\
\text { rib not }\end{array}$ & $\begin{array}{l}\text { swer } \\
\text { vers }\end{array}$ & $\begin{array}{l}\text { durin } \\
\text { uring }\end{array}$ & $\begin{array}{l}\text { an e } \\
\text { n exa }\end{array}$ & xam & $\begin{array}{c}\bar{x} \\
= \\
\text { Vt }\end{array}$ & $\begin{array}{l}\text { Avera } \\
y=C \\
=\text { Ver }\end{array}$ & $\begin{array}{l}\text { egory } \\
\text { Good }\end{array}$ & $\mathrm{G}=\mathrm{C}$ & od, $\mathrm{F}$ & = Fair, & $=\mathrm{Po}$ & \\
\hline
\end{tabular}

In-depth observation during the learning process and examination has been carried out by involving four observers to ensure the accuracy of the observations of the students' behavior. Figure 1 and 2 shows the students' behavior that appear the academic honesty during learning process and examination.

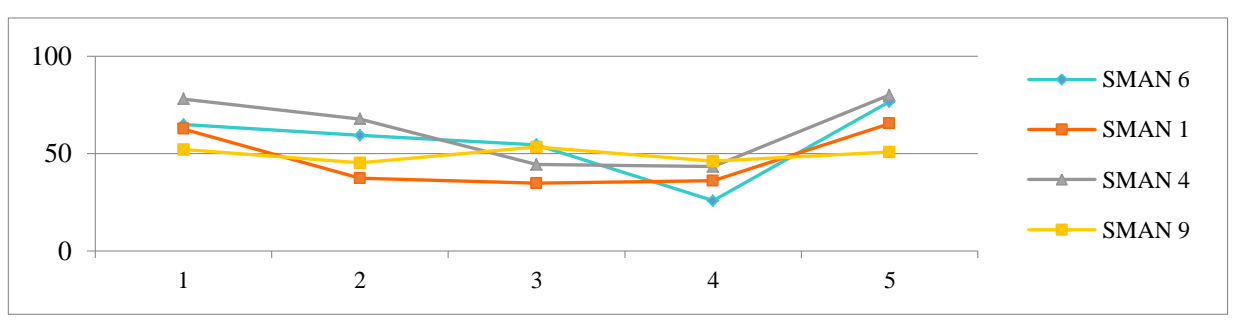

Figure 1

Graphic of experimental group's academic honesty

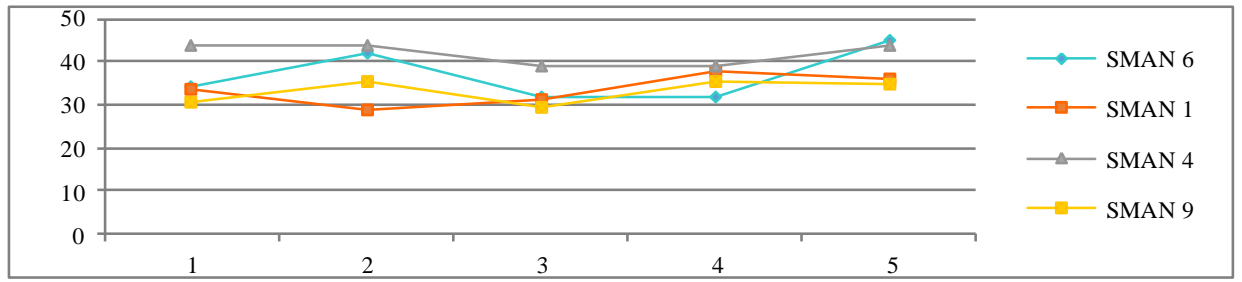

Figure 2

Graphic of controlled group's academic honesty 
The data in tables 4 or graphs 1 and 2 about "doing one's work and making conclusions" on the student worksheets show the positive acquisition as good enough category. This category comes into the students' work results are still not quite right, and there are still many who cheat the assignments of friends, even though students are expected to do it themselves first before being discussed. Likewise, when making conclusions, they faced difficulties in their ideas or unconfident unless asking their friends' answers. This situation indicates that students have not been able to show their confidence in the results of learning or experience gained. Three other aspects, namely, not asking for answers during the exam, not cheating, not seeing notes, for all the experimental and control classes are still very alarming, which is still in the poor category.

From the observation of the students' behavior, students were often not serious in dealing with lessons, distracted with other activities, and challenging to understand the subject matter provided. Also, students tend to move around their seats, looking for friends who are familiar with them. While carrying out the potential test at the end of each lesson and formal test, most students are silent and do not work or write answers. They prefer to ask answers from friends, stand in a chair looking at a friend's answer, pulling a friend's answer paper, asking friends directly any answers needed. It becomes a constraint that significantly interferes with the learning process even though the student has been repeatedly warned.

Table 5

Percentage category of student's academic honesty

\begin{tabular}{|c|c|c|c|c|}
\hline School & Group & $\begin{array}{l}\mathrm{t}_{\text {count }} \\
\mathrm{Z}_{\text {count }}\end{array}$ & $\begin{array}{l}\mathrm{t}_{\text {table }}(\alpha)=0.05 \\
\mathrm{Z}_{\text {table }}(\alpha)=0.05\end{array}$ & Conclusion \\
\hline \multirow[b]{2}{*}{ SMAN 6 Takalar } & Experiment & \multirow{2}{*}{$\mathrm{Z}_{\text {count }}=5.99$} & \multirow{2}{*}{$\mathrm{Z}_{\text {table }}=1.64$} & \multirow{2}{*}{$\mathrm{H}_{1}$ accept } \\
\hline & Control & & & \\
\hline \multirow[b]{2}{*}{ SMAN 1 Gowa } & Experiment & \multirow[b]{2}{*}{$\mathrm{Z}_{\text {count }}=6.18$} & \multirow[b]{2}{*}{$\mathrm{Z}_{\text {table }}=1.64$} & \multirow{2}{*}{$\mathrm{H}_{1}$ accept } \\
\hline & Control & & & \\
\hline \multirow{2}{*}{$\begin{array}{l}\text { SMAN } 4 \\
\text { Makassar }\end{array}$} & Experiment & & & \multirow{2}{*}{$\mathrm{H}_{1}$ accept } \\
\hline & Control & $\mathrm{t}_{\text {count }}=6.18$ & $\mathrm{t}_{\text {table }}=2.00$ & \\
\hline \multirow[b]{2}{*}{ SMAN 9 Maros } & Experiment & \multirow[b]{2}{*}{$\mathrm{t}_{\text {count }}=6.18$} & \multirow[b]{2}{*}{$\mathrm{Z}_{\text {table }}=1, .68$} & \multirow{2}{*}{$\mathrm{H}_{1}$ accept } \\
\hline & Control & & & \\
\hline
\end{tabular}

The hypothesis test in Table 5 shows that learning with the Contextual based Discovery Learning Model influences students' academic honesty. The results at the four schools above indicate the value of zcount > ztable and tcount>ttable, $\mathrm{H} 1$ is accepted, and $\mathrm{H} 0$ is rejected, which means the working hypothesis is accepted, so in general there is an influence of the CDL model on students' academic honesty.

\section{DISCUSSION}

Concerning interviews involving 112 participants on the aspects of academic honesty, students do not concern about academic honesty as the main things that need to be considered in the implementation of learning. It can be seen from the low level of honesty of students when conducting examinations. As the following interviews, 21 percent of the participants responded as they were rarely guided by parents or family at 
home if there are homework assignments or facing exams, even parents are not noticed every night about the readiness of school equipment or lessons the next day. Moreover, less of them $(0.7 \%)$ Advice about behaving honestly or not cheating on friends during exams or assignments from the teacher, never conveyed by parents. Furthermore, the students' responses to chemistry lessons are "all chemistry lessons are difficult for me; many formulas and symbols chemistry that is complicated and difficult to memorize, let alone understood. For acid-base ingredients, we are a little happy because acid and base samples have been used because there are many around us (4.0\%). The results of this study are supported by the results of the study, which found that academic dishonesty has increased in tertiary education rather than because the use of technology and the problem is very significant in jeopardizing class integrity (Sayed \& Lento, 2015; Waithaka \& Gitimu, 2012).

Table 3 appears that the students' ability in the four schools for the experimental group in associating a stimulus with learning objectives is in the categories of fair to good. This situation is related to those who feel confused in determining the direction of the stimulus goal. They tend to have difficulty in writing down the proper objectives or goals for the following syntax of problem identification. It seems that they are less serious, inactive, and unmotivated to try to identify problems that might arise. They tend to ask the teacher and members of the group, and there are only a few who try to work with their thoughts.

The results of problem identification are still in fair to good categories. Most students express any problems that are not yet understood, even if they are not following the learning objectives at the meetings. This situation mostly occurs in the first and second meetings. The main difficulty that students are dealt with is the lack of preparation of fundamental knowledge about the teaching material provided because of only a few of them read well the material of acid-base in the textbook at home. Moreover, it also occurs in the material development of acid-base theory, specifically in calculating the $\mathrm{pH}$ of solutions of weak or strong acid-base.

In the third syntax of data collection, students are given the opportunity for several minutes to discuss with other members in the group and refer to the textbook or online teaching materials. Specifically, acid-base theory materials and concepts, as well as $\mathrm{pH}$ calculation of acid solution, a long duration is available to work out and explore as many learning resources as possible. However, the acid-base test material uses natural and universal indicators. After that, data collection is done through laboratory practicum cooperatively. The performance results in this phase are in the categories of good to very good, which implies an increasing tendency to collect data. At this process, it raises the indications of independence and responsibility as the basics to instill academic honesty. Students will begin to train themselves to discover solutions for the existing problems.

In the fourth syntax of data processing which is conducted after data collection, students process the obtained data by answering correctly and completely the problems that have been identified referred from the data collected. Besides, they have met the criteria as depicted in good to very good categories, which indicates that they can express their 
ideas ly after learning and practicum concerning substances found around them. This syntax is in line with the findings by Tutut (2018), which reveal that learning with a approach enhances students' ability to process learning outcomes data. Similarly, Johnson (2002) further states that learning with a approach is following applicable natural principles so that students learn to express their full potential naturally. The processing results of academic honesty are fully formed through the opportunities given to process their answers from the discussion results. It is to assure that the data processing results of each individual in one group allow using different sentence structures as in its proper meaning. However, many of them are still incorrect. Nevertheless, the group discussion hones their courage to express opinions. Besides, it discussion can increase the students' honesty, objectivity, rationality, and openmindedness.

In the fifth syntax of verification, the students' activities focus on discussing with group members concerning the previous results of data processing. In this phase, the categories of good to very good are obtained. The involved activities engage students to enjoy and utilize well the time duration given to discuss with classmates using their sentences. It seems that only students from SMAN 4 Makassar who are classified in the very good category due to the school that has implemented discovery learning model couples of subjects including chemistry subject. For the other three classes, they are still using conventional models and methods which are dominated by the lecture method. In this phase, it grows confidence, the ability to change the view towards an answer by referring to the evidence from the information collected. In the process of group discussion, it includes exchanging ideas with group members and having the opportunity to revise the results of data processing, respectively, along with the supervision of the teacher for each group to achieve the results of a comprehensive discussion as in learning objectives. However, there are still many students who are unconfident with their answers. They often copy their friends' answers and ignore the teacher's warning when cheating, which is done not only to their close friends, but surprisingly there are even who stand and walk in search of answers during the process.

The sixth syntax of generalization or concluding comprises the students' ability to achieve good to very good categories as only seen in one group class at SMA Negeri 9 Maros with their fair category. Their ability to conclude is more directed. Unfortunately, their weakness is that they still feel difficult to arrange sentences using a standard language, but the core material is already summarized well in a conclusion they made. The observation results showed that many students made their conclusions, especially for the acid-base practicum results using natural materials. It implies that they had conducted inclusively academic honesty as a result of integration between the concepts and facts of the source and learning media.

As referred to on the observation results in Table 3, there are still two syntaxes that are difficult to be achieved properly by students, that is stimulus syntax and problem identification. It is because the stimulus does not describe or the indicators and learning objectives; moreover, if a school has not applied CDL yet, which means that habits cause the students' ability to complete the syntaxes. 
According to Garza (2014), an introduction to academic honesty is necessary given the lack of academic integrity, which can damage the philosophy of education and bias the boundaries of intellectual property so that information is widely available but unknown to its owner. Therefore, many students miss "learning opportunities." Garza further mentioned the importance of an introduction to academic honesty as the solution against the lack of attention to academic violations that occur without a follow-up as a preventive measure.

As the data observation, it finds constraint during the implementation of academic honesty in the academic environment. The first point, there are no clear rules or sanctions for dishonest ones such as cheating during an exam. Secondly, each student commit dishonesty in school in any form, are not considered weak, reasonable, and unusual behavior; there are no sanctions or penalties imposed on them. Thirdly, there is no single subject teacher who integrates the values of academic honesty into character learning.

However, related research conducted by Munir et al. (2011) concluded that the academic honesty of students was still very low. Their study involved nearly 200 students selected from a population of 6749 students of Gujrat University. Their study revealed that all independent variables included in this study played an essential role in differentiating cases through discrimination function, and $74.5 \%$ of cases of student dishonesty were found to be supported by factors of sabotage, electronic fraud, and outside assistance. Moreover, Petrak \& Bartolac (2014) revealed that the moderate prevalence of dishonest behavior, especially in examinations. Students often exhibit dishonest behavior due to inadequate supervision during the exam, while the primary motivation for cheating is passing the exam or getting a higher score. As the significant predictors of academic dishonesty, it was concluded that senior students behaved more honestly. For students who are more honest in academic situations, cheating is less acceptable, and they give more reasons not to cheat and cheat less.

\section{CONCLUSION}

The findings in this study demonstrate the CDL model integrated with acid-base subjects obtained through descriptive statistical analysis indicates the aspects of academic honesty to do their tasks and conclude their learning outcomes are included in the category of sufficient and proper. However, the aspects do not ask friend answers, not cheating, and not seeing notes when the exam is still not a good category. The results also indicates there was an influence of the CDL model on the academic honesty of high school students. This proves that academic honesty can be trained through the stages of learning in the classroom. Future studies can compare academic honesty between male and female students through CDL model.

\section{REFERENCES}

Anderman E. M., \& Koenka A. C. (2017). The relation between academic motivation and cheating. Theory into Practice, 56(2), 95-102. 
Bolin, A. U. (2004). Self-control, perceived opportunity, and attitudes as predictors of academic dishonesty. The Journal of Psychology, 138(2), 101-114.

Brew, A., \& Sachs, J. (2007). Transforming a university: the scholarship of teaching and learning in practice. Sydney: Sydney University Press.

Davis, S. F., \& Drinan, P. F. (2009). Cheating in school. Wiley Online Library.

Garza, C. (2014). Academic honesty - principles to practice. IB Africa, Europe \& Middle East Regional Conference. Rome.

Gizhitsky V. (2014) Uchebny obman kak strategiya psevdoadaptivnogo povedeni-ya u starsheklassnikov [Cheating as maladaptive behavior strategy of high school students]. Scientific Notes of Orel State University. Series Humanities and Social Sciences, 2, 293-299.

Gizhitsky V., Gordeeva T. (2015) Strategii uchebnogo povedeniya kak media-tory vliyaniya motivov na akademicheskie dostizheniya [Academic behavior strategies as mediators of motives' influencing the academic achievement]. Scientific Notes of Orel State University. Series Humanities and Social Sciences, 2, 253-259.

Halimah, S., \& Paramma, M. A. (2019). Attitudes and approaches of the EFL teachers on scientific approach in Indonesian school context. Asian EFL Journal, 23(3.3), 386397.

Johnson, E. B. (2002). Contextual teaching and learning: what it is and why it's here to stay. SAGE Publications. Retrieved from https://books.google.co.id/books?id=2HRoigMMdqMC

Khotimah, S. K., Fadhli, M. I., \& Habibi, Y. (2017). Meningkatkan kejujuran akademik: efektivitas classroom developmental bibliotherapy dalam pembelajaran. Humanitas: Jurnal Psikologi Indonesia, 14(2), 90-102.

Koesoema, D. (2010). Pendidikan karakter: strategi mendidik anak di zaman global (Second Ed.). Jakarta: Grasindo.

Kustyarini, K. (2020). Self efficacy and emotional quotient in mediating active learning effect on students' learning outcome. International Journal of Instruction, 13(2), 663676.

Langa, C. (2013). Investigation of students' attitude to academic honesty-empirical study. Procedia-Social and Behavioral Sciences, 76, 426-430.

Ledwith, A., \& Rísquez, A. (2008). Using anti-plagiarism software to promote academic honesty in the context of peer reviewed assignments. Studies in Higher Education, 33(4), 371-384.

Morris, E. J. (2018). Academic integrity matters: five considerations for addressing 
contract cheating. International Journal for Educational Integrity, 14(1), 15.

Munir, M., Ahmad, Z., \& Shahzadi, E. (2011). A study on academic dishonesty of university students. Recent Advances in Statistics, 285.

Naghdipour, B., \& Emeagwali, O. L. (2013). Students' justifications for academic dishonesty: call for action. Procedia - Social and Behavioral Sciences, 83, 261-265.

Petrak, O., \& Bartolac, A. (2014). Academic honesty among the students of health studies. Croatian Journal of Education, 16(1), 81.

Salfrika, T. (2016). Pengembangan Handout berbasis kontekstual pada materi faktorfaktor yang mempengaruhi laju reaksi untuk SMA/MA kelas XI IPA. Jurnal Ilmiah Mahasiswa Pendidikan Kimia, 1(3).

Sayed, N., \& Lento, C. (2015). The impact of technology on academic dishonesty: Perspectives from accounting faculty. Available at SSRN 2655615.

Shmeleva E. (2016) Plagiat i spisyvanie v rossiyskikh vuzakh: rol' obrazovatel'noy sredy i individual'nykh kharakteristik studenta [Plagiarism and cheating in russian universities: the role of the learning environment and personal characteristics of students]. Voprosy obrazovaniya/Educational Studies Moscow, 1, 84-109.

Shmeleva, E., \& Semenova, T. (2019). Academic Dishonesty among College Students: Academic Motivation vs. Contextual Factors. Educational Studies, 3, 101-129.

Sims, R. L. (1993). The relationship between academic dishonesty and unethical business practices. Journal of Education for Business, 68(4), 207-211.

Sugiarti, M., \& Husain, H. (2019). The Correlation between academic honesty and a students' curiosity with the results of learning based on discovery learning. 1st International Conference on Advanced Multidisciplinary Research (ICAMR 2018). Atlantis Press.

Sugiyono. (2017). Metode penelitian pendidikan:(pendekatan kuantitatif, kualitatif dan $R \& D$ ). Bandung: Alfabeta.

Sugano, S. G. C., \& Nabua, E. B. (2020). Meta-analysis on the effects of teaching methods on academic performance in chemistry. International Journal of Instruction, 13(2), 881-894.

Tutut, I. (2018). Upaya meningkatkan kemampuan pengolahan data dalam pelajaran matematika melalui penerapan model pembelajaran kontekstual siswa kelas VI SDN Glanggang I semester I tahun ajaran 2013/2014. Jurnal Ilmiah Edukasi \& Sosial, 7(2), $105-114$.

Waithaka, A. G., \& Gitimu, P. (2012). Academic dishonesty-team effort against it; a review of literature. Journal of Academic and Business Ethics, 6(1). 
Yusuf, A. M. (2016). Metode penelitian kuantitatif, kualitatif \& penelitian gabungan. Jakarta: Prenada Media. 